Inventing the Classics 



\section{Inventing the Classics}

MODER ITY, NATIONAL I DEN TITY, AND JAPANESE LITERATURE

Edited by

Haruo Shirane

and Tomi Suzuki

STANFORD UNIVERSITY PRESS

STANFORD, CALIFORNIA 
Stanford University Press

Stanford, California

(C) 2000 by the Board of Trustees of the

Leland Stanford Junior University

Library of Congress Cataloging-in-Publication Data

Inventing the classics : modernity, national identity, and Japanese literature / edited by Haruo Shirane and Tomi Suzuki

p. $\mathrm{cm}$.

Includes bibliographical references and index.

ISBN 0-8047-3990-O (alk. paper)--ISBN 0-8047-4105-O (paper :

alk paper)

I. Japanese literature-History and criticism. 2. Nationalism and literature-Japan. 3. Ideology and literature. 4. Nationalism and education-Japan. I. Shirane, Haruo, 195III. Suzuki, Tomi, I95I-

PL714.158 200I

$895.609-\mathrm{dc} 21$ oo-0058337

Rev.

Typeset by BookMatters in II/13 Adobe Garamond

Original Printing 2000

Last figure below indicates year of this printing:

$\begin{array}{llllllllll}09 & 08 & 07 & 06 & 05 & 04 & 03 & 02 & \text { or } & 00\end{array}$ 